Apidologie, 1983, 14 (4), 333-341.

\title{
PATHOGENESIS OF CHALKBROOD IN THE ALFALFA LEAFCUTTING BEE, MEGACHILE ROTUNDATA
}

\author{
John D. VANDENBERG* and W. P. STEPHEN \\ Deparment of Entomolog. \\ Oregon State liniversits \\ Corrullis, O.R. 97331. U.S.A
}

\section{SUMMARY}

Chalkbrood is a mycosis of larvae of certain Hymenoptera including the alfalfa leafcutting bee, Megachile rotundata. Basic studies were conducted to determine the course of pathogenesis in afflicted larvae. Ascosphaera aggregata spores germinated in the midguts and penetrated the hemocoel of fourth instar larvae within 2 days after inoculation. Invasion of epidermis, tracheae and muscles followed within 3 more days. The entire hemocoel was nearly filled with mycelium at the time of death, 3-7 days after inoculation.

\section{INTRODUCTION}

Chalkbrood is a mycosis of certain hymenopteran larvae. The disease is a serious problem for alfalfa seed growers in western North America who use populations of Megachile rotundata (Fabricius) for pollination (STEPHEN and UNDURRAGA, 1978). The etiology of chalkbrood in this host and the signs by which it may be recognized were reported earlier (VANDENBERG and STEPHEN, 1982, 1983). Spores of Ascosphaera aggregata SKOU cling to emerging adults of $M$. rotundata as they chew through spore-laden chalkbrood cadavers (VANDENBERG et al., 1980). Some adults carry spores throughout their lives (STEPHEN et al., 1981) and may contaminate their mates, eggs, and pollen provisions. Developing larvae are invaded by spores germinating in the gut. In this paper the course of infection from ingestion of spores until host death is described.

\footnotetext{
* Current address : U.S.D.A.-A.R.S., Bioenvironmental Bee Lah., Beltsville, M.D. 20705.
} 

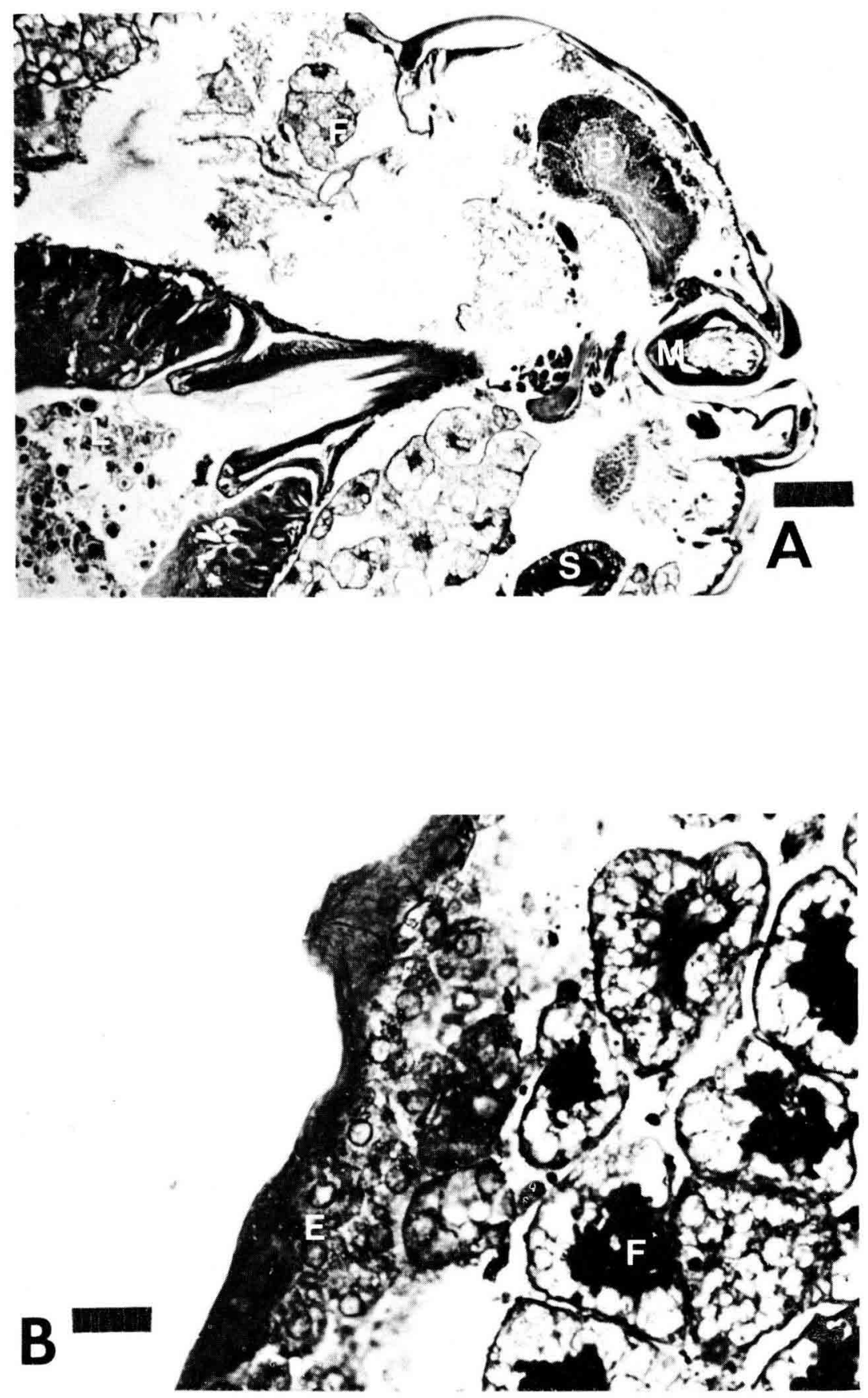

Fici. 1. - Head and thorax (A) and epidermis and cuticle (B) of uninfected Megachile rotundata larrae. A) Mallory triple stain. Bar $=120 \mu \mathrm{m}$. B) Periodic acid-Schiff reagent.

Bar $=30 \mu \mathrm{m} . \mathrm{B}=$ brain. $E=$ epidermis. $F=$ fat body $\mathrm{L}=$ lumen of the gut. $\mathrm{M}=$ mandible. $\mathrm{S}=$ silk gland. 
Larvae were reared on an autoclaved, pollen-based diet in individual wells of polystyrene titration plates (Fichtile 't al., 1981). Fresh diet was inoculated with spores of A. aggregata at a dose of $10^{5}$ spores per larva as described by VAVDENBLRC; and STPPII (1982). Disease-free third and fourth instar larvae were transferred to the inoculated diet and allowed 10 feed at $30 \% \mathrm{C}$. Beginning at 24 hours post-inoculation and at 12 to 24 hour intervals for 8 days, larvate were fixed for histological processing in alcoholic Bouin's fluid or buffered formalin (HuMASON, 1972). Samples were dehydrated in a graded ethanol series and cleared in toluene. Alternately, dioxane was used for both the dehydration and clearing. Paraplast $\AA_{--}$plus (Sherwood Medical, St. Louis) was used as the embedding medium. Sections were made at $8-10 \mu \mathrm{m}$, affixed with Mayer's albumin to glass slides, and stained with hematoxylin and eosin. Mallory's triple stain, periodic acid-Schiff reagent or Gomoris methenamine silver nitrate (HLMASON, 1972). Sections were examined for the presence of fungal growth within the host and photographed. Other cleared and dehydrated sections were examined by scanning electron microscopy

\section{RESUITS AND DISCUSSION}

Chalkbroc 1 pathogenesis begins with $A$. aggregata spore germination in the midgut of $I$. rotundata larvae and subsequent invasion of the host hemocoel. $U$ infected $M$. rotundata larvae are shown in Fig. 1 . Some gut contents including pollı a grains can be seen in Fig. la. Healthy epidermal and fat body tissues are visil e in Fig. 1b. Germ tube formation by $A$. aggregata within the host midgut and $m y$ :elial penetration of the peritrophic lining occurred within 1-3 days after inoculatic 1 of fourth instar larvae (Fig. 2). The mechanisms by which germ tubes penetratı the peritrophic lining have not been studied but may involve extracellular el zyme production or mechanical disruption of this barrier. No spores were ob erved to germinate on the outer surface of the host. Within 2-4 days, fungus hy phae were detected in the host hemocoel invading the epidermis, tracheae (Fig. 3 and muscles (Fig 4 a). External signs of infection are not visible until the host ; near ieath and nearly filled with fungus mycelium (Fig. 4b, Vandenberg at d StePhen, 1982). Fungus sporulation occurs beneath the host cuticle (SKOU, 1 175) within 1-2 weeks after host death.

Following ,ermination in vitro in high $\mathrm{CO}_{2}$ concentrations (KISH, 1980; STEPHEN et al., 982), mycelial cultures isolated from germ tubes of $A$. aggregata thrive on the sur ace of agar exposed to air and resemble those within infected hosts (VANDENBERG a d STEPHEN, 1982). However, some spores will germinate in vitro when incubated $n$ the presence of air instead of $\mathrm{CO}_{2}$ (VANDENBERG, 1982). Neither reduced oxygen 10r $\mathrm{CO}_{2}$ requirements were reported by SKOU (1975) when isolating this fungus. Studies on $p \mathrm{H}$ and oxidation-reduction potentials in the guts of uninfected $M$. rotundata larvae indicate that conditions of reduced potential and near neutral $p \mathrm{H}$ exist (VANDENBERG, 1982). The influence of host gut conditions on spore germination by $A$. aggregata has not been explored 

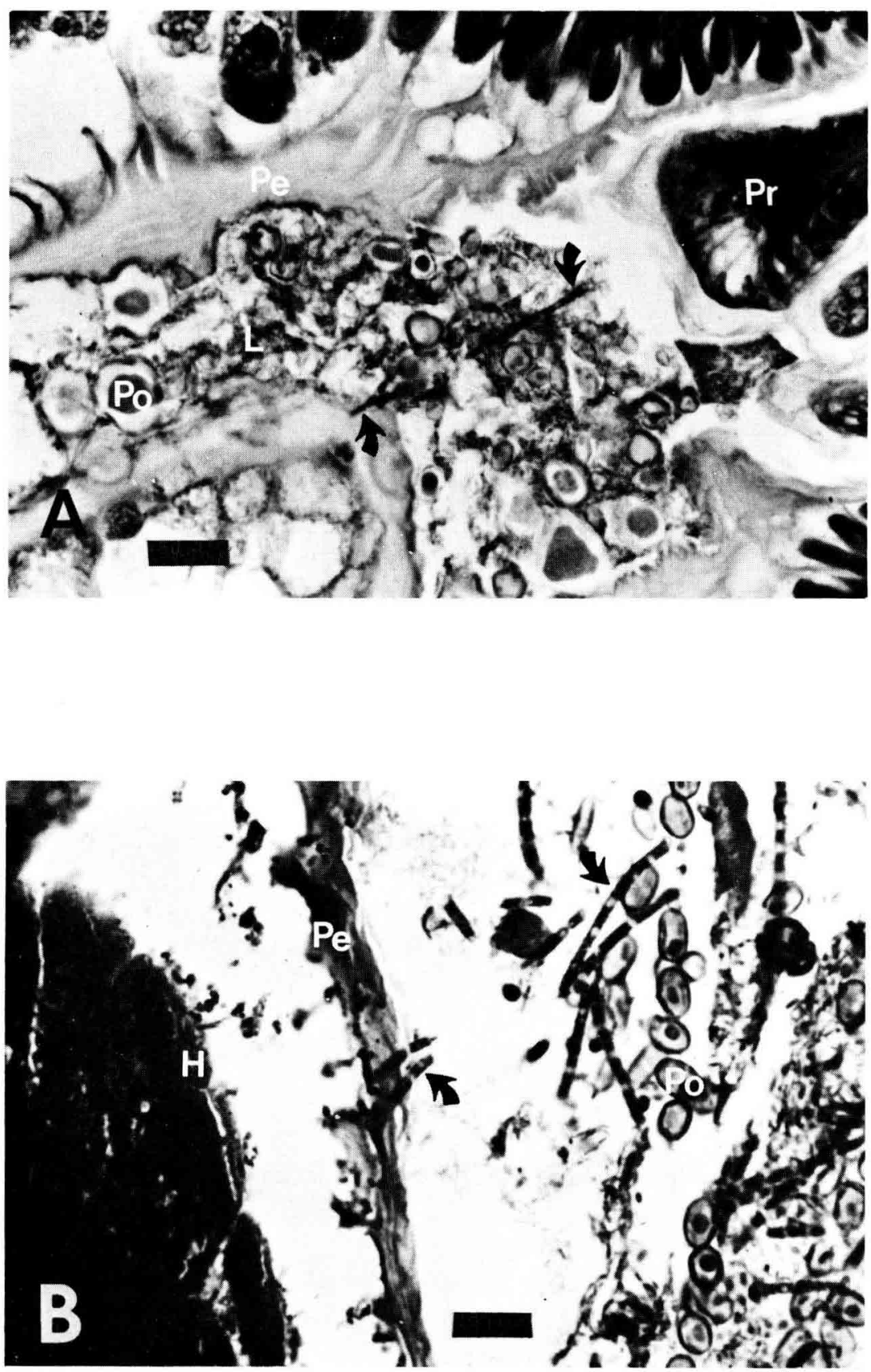

Fig. 2. - Germ tubes of Ascosphaera aggregata in this midgut of Megachile rotundata larvae, near the proventriculus $(A)$, and the peritrophic lining $(B)$.

A) Hematoxylin and eosin. Bar $=30 \mu \mathrm{m}$. B) Mallory triple stain. Bar $=20 \mu \mathrm{m}$. Arrows $=$ germ tubes, $\mathrm{H}=$ hemocoel, $\mathrm{L}=$ lumen of the gut. $\mathrm{Pe}=$ peritrophic lining, $\mathrm{Po}=$ pollen, $\mathrm{Pr}=$ proventriculus. 

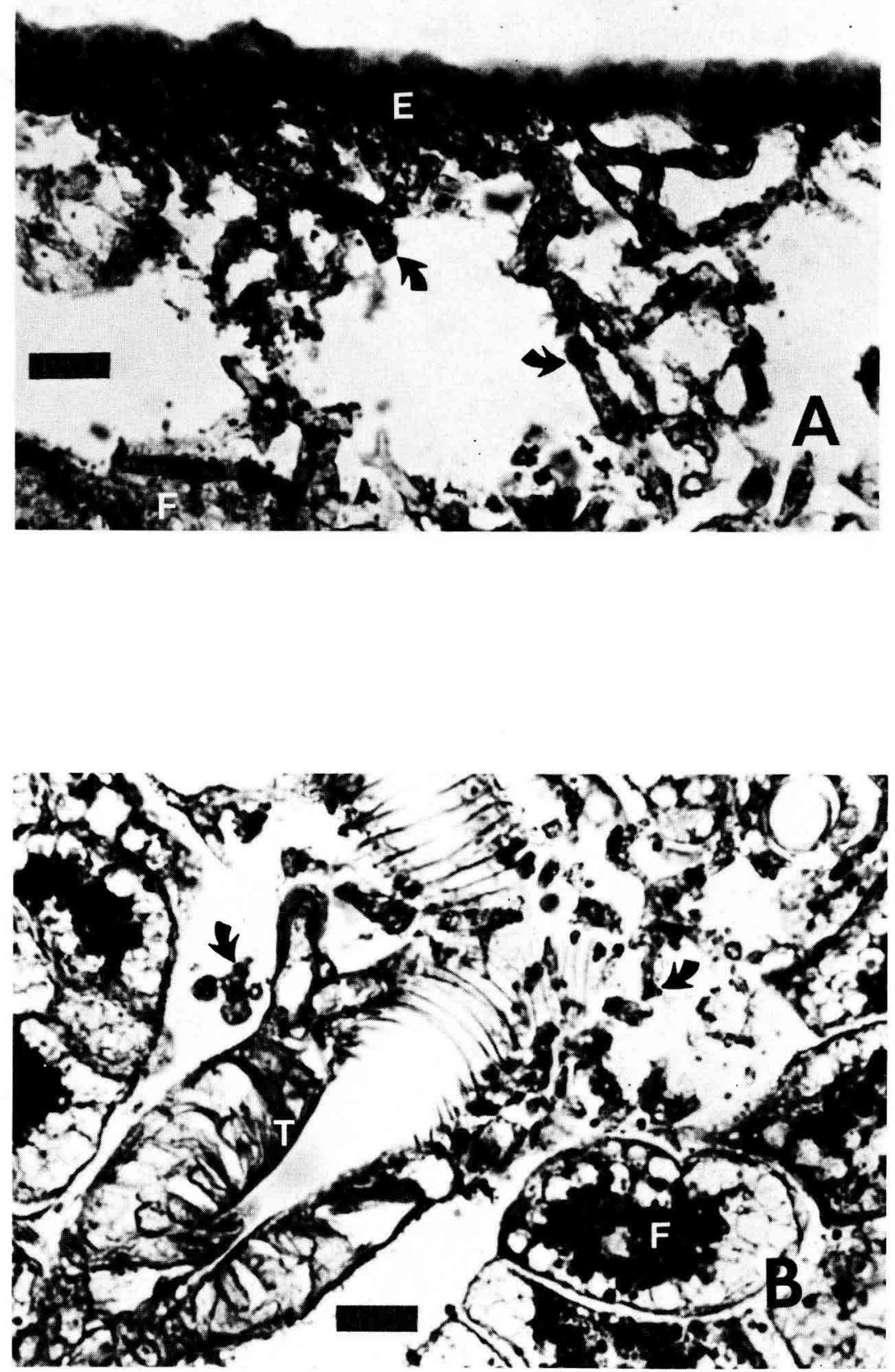

FIG. 3. - Ascophaera aggregata mycelia in the epidermis (A) and trachea (B) of Megachile rotundata larvae.

A) Periodic acid-Schiff reagent. Bar $=30 \mu \mathrm{m}$. B) Mallory triple stain.

Bar $=30 \mu \mathrm{m}$. Arrows $=$ hyphae, $E=$ epidermis, $F=$ fat body, $T=$ trachea. 

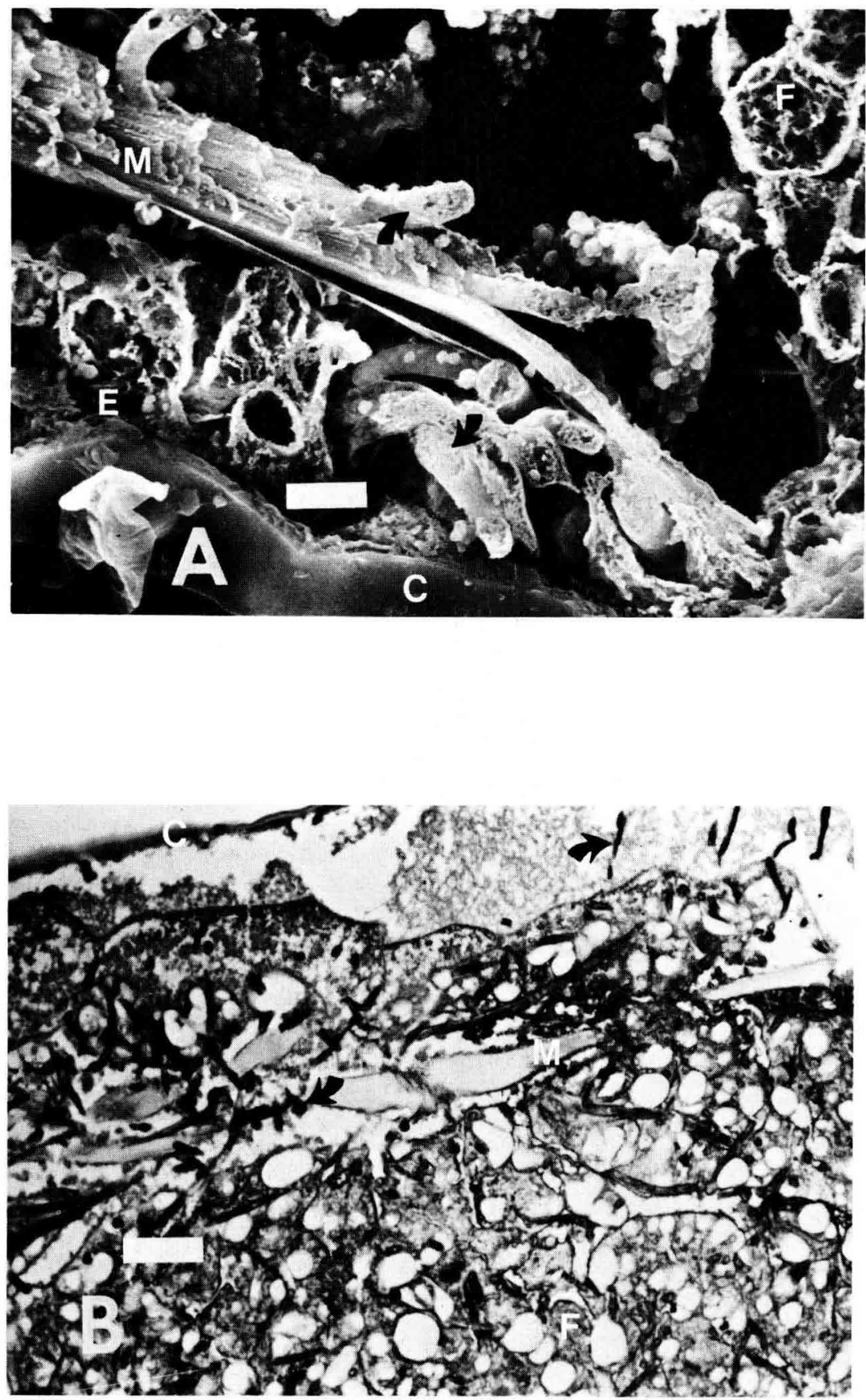

FIG. 4. - Ascosphaera aggregata mycelia in muscle and epidermis $(A)$, and in the hemocoel (B) of Megachile rotundata larvae.

A) Scanning electron micrograph. Bar $=10 \mu \mathrm{m}$. B) Gomori methenamine-silver nitrate. Bar $=40 \mu \mathrm{m}$. Arrows $=$ hyphae, $\mathrm{C}=$ cuticle, $\mathrm{F}=$ fat body, $\mathrm{M}=$ muscle. 
The causative agent of chalkbrood in honey bees, Apis mellifera L., is Ascosphaera apis (Maasen ex Claussen) Olive et SPILtoir (BAiley, 1967; MAurizio, 1934), although its route of entry into the insect is open to question (GILLIAM, 1978). MaUrizio (1934) found the fungus in the intestines of larvae from infected colonies. BAILEY (1967) suggested that chilling of larvae resulted in increased oxygen levels in the gut and allowed renewed growth of germ tubes and mycelia of A. apis. Other workers claim that spores of $A$. apis may germinate within the gut or outside the host and then penetrate the cuticle (GILliam et al., 1978; GLINSKY, 1981; Roussy, 1962). They applied spore suspensions to mouth-parts or dorsal cuticle and observed resulting mummy formation. Although GILLIAM et al. (1978) observed the fungus growing on the outer surface of larvae that later succumbed to infection, neither they, GLINSKY (1981), nor RouSSY (1962) examined gut contents for germinating spores. It is possible that application of spores to the cuticle was followed by larval ingestion of inoculum during the course of incubation. Infection followed $A$. apis spore germination in the gut. In order to rule out this possibility, means must be devised to prevent larvae from ingesting spore inoculum.

We have shown here that spores of $A$. aggregata ingested by larvae of $M$. rotundata germinate within the host midgut. Penetration of the peritrophic membrane and ramification within various host tissues follows within 1 week. External signs of infection are not apparent until shortly before host death, by which time the fungus has nearly filled the host hemocoel. Spores on the outer surfaces of hosts were not observed to germinate although some spores incubated in vitro on a nutrient medium in the presence of air will germinate (VANDENBERG, 1982).

\section{ACKNOWLEDGMENTS}

The authors thank Drs. J. C. Leong, M. E. Martignoni, E. W. Herbert, Jr., and H. Shimanuki for reviews of a draft of this manuscript. Al Soeldner provided assistance with the electron microscopy.

This research was supported by the Multistate Chalkbrood Project, a consortium of grower groups and industry representatives in Idaho, Nevada, Oregon and Washington; the Idaho, Nevada and Washington Alfalfa Seed Commissions; the Universities of Idaho and Nevada-Reno; Oregon, Utah and Washington State Universities; and the U.S.D.A./A.R.S. Wild Bee Laboratory, Logan, Utah.

This work is Oregon Agricultural Experiment Station Technical Paper No. 6829 and is based on part of a thesis by the first author in partial fulfillment of the requirements for the $\mathrm{Ph}$. D. degree at Oregon State University. 


\section{RÉSUMÉ \\ PATHOGENĖSE DU COUVAIN PLATRÉ CHEZ LA MÉGACHILE, MEGACHILE ROTUNDATA}

Le couvain plâtré est une mycose qui attaque les larves de certains Hyménoptères, dont la mégachile de la luzerne, Megachile rotundata. On a mené des études de base afin de déterminer le déroulement de la pathogenèse chez les larves atteintes.

Des æufs récoltés en plein air ont été désinfectés en surface, puis placés en laboratoire sur un milieu nutritif à base de pollen. Les larves des 3 e et 4 e stades ont été transférées sur un milieu nutritif frais auquel on avait inoculé des spores d'Ascosphaera aggregata, l'agent responsable du couvain plâtré chez $M$. rotundata. On a fixé les larves à intervalles réguliers après inoculation, puis effectué des coupes à la paraffine, examinées ensuite au microscope optique et au microscope électronique à balayage.

Les spores d'Ascosphaera aggregata ont germé dans l'intestin moyen et pénét ré dans l'hémocèle des larves du $3^{\mathrm{e}}$ et $4^{\mathrm{e}}$ stade, 2 jours après l'inoculation. L'invasion de l'épiderme, des trachées et des muscles s'est produite trois jours plus tard. Au moment de la mort, de 3 à 7 jours après l'inoculation, l'hémocèle était presqu'entièrement rempli de mycelium. Les signes externes de la maladie ne sont apparus que peu de temps avant la mort de l'hôte.

Le couvain plâtré chez. l'abeille domestique, Apis mellifica. peut être causé par l'ingestion de spores d'Ascosphaera apis, mais peut aussi survenir à la suite de la germination des spores sur la cuticule extérieure et de leur pénétration ultérieure dans l'hémocèle. On a observé que les spores $A$. aggragata utilisées dans cette étude ne germaient qu'à l'intérieur de l'intestin moyen des larves hôtes. Le taux de germination in vitro le plus élevé est obtenu lorsque les spores sont placées en incubation sur un milieu nutritif en présence d'une concentration élevée de gaz carbonique. Le potentiel d'oxydo-réduction dans l'intestin des larves de $M$. rotundata indemnes est faible, mais on ne sait pas si cette condition est nécessaire à la germination in vivo des spores d'A. aggregata.

\section{ZUSAMMENFASSUNG}

PATHOGENESE DER KALKBRUT BEI DER LUZERNEN-BLATTSCHNEIDERBIENE, MEGACHILE ROTUNDATA

Kalkbrut ist eine Mykose der Larven von verschiedenen Hymenopteren, zu denen auch die Luzernen-Blattschneiderbiene, Megachile rotundata, gehört. Zur Untersuchung des Verlaufs der Pathogenese bei befallenen Larven wurden grundlegende Experimente durchgeführt.

Im Freien gesammelte Eier wurden auf der Oberfläche desinfiziert und im Labor auf pollenhaltige Nahrung gesetzt. Larven des 4. und 5. Stadiums wurden auf frische Nahrung gesetzt und mit Sporen von Ascosphaera aggregata, dem Verursacher der Kalkbrut bei der Luzernen-Blattschneiderbiene, beimpft. Nach der Fixierung der Larven in regelmäßigen Zeitabständen nach der Inoculation wurden Paraffinschnitte angefertigt und sowohl im Licht- wie auch im Rasterelektronenmikroskop ausgewertet.

Ascosphaera aggregata-Sporen keimten im Mitteldarm und penetrierten das Hämocoel des 4. Larvenstadiums bereits 2 Tage nach der Inoculation. Die Invasion der Epidermis, der Tracheen und Muskeln erfolgte innerhalb der drei folgenden Tage. Das gesamte Hämocoel war zur Zeit des Todes 3 bis 7 Tage nach der Inoculation - angefüllt mit Myzel. Äußerliche Anzeichen für die Krankheit waren bis kurz vor dem Tod des Wirts nicht sichtbar.

Die Kalkbrut der Honigbiene, Apis mellifera, entsteht durch Aufnahme der Sporen von Ascosphaera apis durch die Bienenlarve, kann aber auch durch Sporenkeimung auf der Kutikula und anschließendes Eindringen in das Hämocoel hervorgerufen werden. Sporen von A. aggregata, die in diesen Untersuchungen verwendet wurden, keimten nur im Mitteldarm der Wirtslarve. Die höchste Keimrate in vitro wurde erzielt, wenn die Sporen auf einem Nährmedium bei erhöhter Kohlendioxidkonzentration 
inkubiert wurden. Obgleich im Darm von nicht befallenen $M$. rotundata-Larven ein reduziertes Oxidations-Reduktions-Potential herrscht, ist nicht bekannt, ob dieses für die Keimung von $A$. aggregata Sporen in vivo notwendig ist.

\section{BIBLIOGRAPHY}

BAitiY L., 1967. -- The effect of temperature on the pathogenicity of the fungus, Ascosphaera apis, for larvae of the honey bee. Apis mellifera. In P. A. van der Laan (ed.). Insect Pathology and Microbial Control. North-Holland, Amsterdam. pp. 162-1.67.

Fichter B. L., W. P. StePhen and J. D. VANDENBerG, 1981. - An aseptic technique for rearing larvae of the leafcutting bee Megachile rotundata. J. Apic. Res, 20, 184-188.

Gill.1nм M., 1978. - Chalkbrood : status today and hopes for control. Amer. Bee J., 118, 468-471.

Gilliam M., S. TABtR. III and J. BRAy Rosi:, 1978. - Chalkbrood disease of honey bees, Apis mellifera L. : a progress report. Apidologie. 9, 75-89.

GIINSKI Z., 1981. - Studies on the effect of the fungus Ascosphaera apis on larvae of the honey bee, Apis mellifera L. Polskie Archiw'um Weternaryine, 23, 9-15

Humason G. L., 1972. - Animal tissue techniques, 3rd edition. W. H. Freeman, San Francisco.

KISH L. P., 1980. - Spore germination of Ascosphaera spp. associated with the alfalfa leafcutting bee, Megachile rotundata. J. Invertebr. Pathol, 36, 125-128.

Maurizio A., 1934. - Über die Kalkbrut (Pericystis-Mykose) der Bienen. Arch. Bienenk., 15, 165-193.

Roussy L., 1962. - Nouvelle contribution à l’étude du Pericystis apis (Mn). Gazette Apicole. 63, $101-105$.

Skou J. P., 1975. - Two new species of Ascosphaera and notes on the conidial state of Bettsia alvei. Friesia, 11, 62-74.

Stephen W. P. and J. M. Undurraga, 1978. - Chalkbrood disease in the leafcutting bee. Ore. State Univ. Agric. Exp. Sta. Bull. 630. Corvallis, Ore.

Stephen W. P., J. D. Vandenberg and B. L. Fichter, 1981. - Etiology and epizootiology of chalkbrood in the leafcutting bee, Megachile rotundata (Fabricius), with notes on Ascosphaera species. Ore. State Univ. Agric. Exp. Sta. Bull. 653. Corvallis, Ore.

Stephen W. P., J. D. VandenberG, B. L. Fichter and G. Lahm, 1982. - Inhibition of chalbrood spore germination in vitro. Ore. State Univ. Agric. Exp. Sta. Bull. 656. Corvallis, Ore.

VANDEnBERG J. D., 1982. - Etiology and pathogenesis of chalkbrood in the alfalfa leafcutting bee, Megachile rotundata. Ph. D. Dissertation, Oregon State University, Corvallis.

Vandenberg J. D., B. L. Fichter and W. P. Stephen, 1980. - Spore load of Ascosphaera species on emerging adults of the alfalfa leafcutting bee, Megachile rotundata. Appl. Environ. Microbiol., 39, 650-655.

VAndenberg J. D. and W. P. STEPHEN, 1982. - Etiology and symptomatology of chalkbrood in the alfalfa leafcutting bee, Megachile rotundata. J. Invertebr. Pathol., 39, 133-137.

Vandenberg J. D. and W. P. StePhen, 1983. - Pathogenicity of Ascosphaera species for larvae of Megachile rotundata. J. Apic. Res., 22, 57-63. 